PRINT ISSN 1119-8362

Electronic ISSN 1119-8362
Full-text Available Online at

https://www.a.jol.info/index.php/jasem

http://ww.bioline.org.br/ja
J. Appl. Sci. Environ. Manage.

Vol. 25 (9) 1637-1644 September 2021

\title{
Morphological, Phytochemical and Molecular Characterization of five common Jatropha species in the Niger Delta Region of Nigeria
}

\author{
* ODOGWU, BA; UKOMADU, J AND IGWE, I
}

\author{
Department of Plant Science and Biotechnology, Faculty of Science, University of Port Harcourt. Choba, P. M. B. 5323, Port Harcourt, \\ Nigeria \\ *Corresponding author Email: blessing.odogwu@uniport.edu.ng, Tel: +234 8036772711 \\ Other authors Email: josephine.ukomadu@uniport.edu.ng, Tel: +234 8147651600, ifeanyigwe2018@ gmail.com, Tel: +2348119639427
}

\begin{abstract}
The economic and medicinal important genus Jatropha contains many distinctly different species. To elucidate the genetic relationship of five common occurring Jatropha species namely J. multifida, J. podagrica, $J$. tanjorernsis, J. curcas, and J. gossypifolia, thirty-nine morphological, six phytochemical features and one arbitrary marker was used to screen and explore their similarity. Morphological data was obtained from the measurement of vegetative and reproductive parts while the presence of five phytochemicals was determined using different phytochemical tests. The DNA of all five Jatropha species were amplified and sequenced using Ribolose 1, 5biphosphate carboxylase molecular marker. The DNA sequences were then aligned using the Basic Local Alignment Search Tool for nucleotide 2.8.0 version of the National Center for Biotechnology Information database and phylogenetic trees were constructed using Paleontological Statistical software and Molecular Evolutionary Genetics Analysis version 7.0.26 software. From the results of the classical and phylogenetic cluster analysis, the five Jatropha species was separated into two major clusters. The highly distinctive J. gossypifolia was the only species that clustered separately from the other Jatropha species. Although, J. tanjorensis has been reported to be a hybrid from J. curcas and $J$. gossypifolia, the species did not segregate and cluster with these species, but segregated with $J$. multifida, and $J$. podagrica, indicating that this species is more closely related to $J$. multifida, and $J$. podagrica than $J$. curcas and $J$. gossypifolia. The result therefore provide information that would be useful in the plant improvement programs for the genus Jatropha.
\end{abstract}

\section{DOI:https://dx.doi.org/10.4314/jasem.v25i9.15}

Copyright: Copyright (C) 2021 Odogwu et al. This is an open access article distributed under the Creative Commons Attribution License (CCL), which permits unrestricted use, distribution, and reproduction in any medium, provided the original work is properly cited.

Dates: Received: 09 May 2021; Revised: 12 August 2021; Accepted: 12 September 2021

Keywords: Jatropha curcas, phytochemicals, PAST software, MEGA software

The genus Jatropha is comprised of approximately 175 species that include succulent plants, shrubs, and trees (Nwokocha et al., 2012). The genus is made up of flowering plants in the spurge family Euphorbiaceae. The name 'Jatropha was derived from the Greek words 'iatros', meaning "physician", and 'trophe' meaning "nutrition", hence the common name physic nut (Heller 1996). Most of Jatropha species are native to the Americas, with 66 species found in Africa, Asia and Europe (Nwokocha, 2010). The major species comprise of Jatropha curcas, Jatropha gossypifolia, Jatropha tanjorensis, and Jatropha podagrica, which are closely related to economically important cultivated plants like Manihot esculenta [cassava], Hevea brasiliensis [rubber tree], and Ricinus communis [castor bean] (Heller 1996; ElMewafy et al., 2016). These species are widely distributed in the tropical and sub-tropical areas of the world (Li et al., 2009). Although, seeds of Jatropha species contains compounds that are highly toxic, the plants have proven to be of economic importance, from medicinal utilization to industrial usage, especially in the production of environmentalfriendly energy products, such as bio-fuel, bio-diesel, bio-lubricants from Jatropha curcas, which are renewable resource and a safe source of energy and a viable alternative to petroleum products (Banerji et al., 1985;; Basha and Sujatha, 2007). Presently, most research on Jatropha species are focused mostly on the distribution areas, cultivation and nursery development of Jatropha curcas (Wenjun et al., 2008) and research on its relatives are limited (Sudheer et al., 2009). Furthermore, Jatropha species are incipiently domesticated with no availability of stable and commercial cultivars with high oil content, and tolerance to pests and diseases that can meet the needs of stakeholders of the value chain of these plants such as farmers and processors of the feedstock produced. Therefore, the establishment of Jatropha species as a commercially viable crops requires the development of a suitable genetic crop improvement program (Argolo-Marques et al., 2013). However, the challenge in the improvement of Jatropha species has been the lack of genetic resource for the crop 
improvement program. Therefore, the aim of this study is to use three lines of taxonomic evidences namely, morphology, phytochemistry and using an arbitrary molecular maker, to provide information that will elucidate the genetic variability and explore their similarity to establish their relatedness for use in the conservation and genetic improvement of the genus Jatropha species.

\section{MATERIALS AND METHODS}

Plant and sample collection: Five species of Jatropha namely J. multifida, J. gossypifolia, J. tanjorensis, $J$. podagrica and J. curcas were used in this study (Table 1). These Jatropha species were collected from the 'Fear of God Horticultural Gardens', along NTA road, Ozuoba (geographical coordinates: $4^{0} 52$ ' 44" North, $6^{0} 55^{\prime} 20^{\prime}$ 'East), Port Harcourt, Rivers State, Nigeria. They were identified at the Research Herbarium of the Department of Plant Science and Biotechnology, University of Port Harcourt. Vegetative and reproductive plant parts such as the stem, leaves, petiole, flowers and fruit respectively were collected, documented and deposited at the Herbarium.

Table 1: The taxonomy of some common Jatropha species in Nigeria

\begin{tabular}{ll}
\hline Jatropha species & Common names \\
\hline jatropha podagrica & $\begin{array}{l}\text { Buddha belly plant, bottle plant shrub, gout plant, purging-nut, Guatemalan } \\
\text { rhubarb, and gouty-stalk nettle-spurge. }\end{array}$ \\
Jatropha tanjorensis & $\begin{array}{l}\text { Catholic vegetables, Hospital too far. } \\
\text { Jatropha curcas }\end{array}$ \\
Patropha multifida nut, Barbados nut, poison nut, bubble bush or purging nut. \\
Jatropha gossypifra & Coral plant, coral bush and physic nut. \\
\hline
\end{tabular}

Morphological studies: A study of the plant morphological features of the five mature plant stands of the Jatropha species were carried out. The description of the morphological features was conducted using the Flora of West Tropical Africa by Hutchinson and Dalziel (1958), and Taxonomy of Flowering Plants by Gill (1988). Data was collected for the length and width of vegetative parts such as the leaves, petioles and internodes, and reproductive parts such as the flowers, fruits and seeds were measured using a $30 \mathrm{~cm}$ meter rule.

Phytochemical Studies: Fresh leaves of each of the five Jatropha species were collected, washed in distilled water and air-dried under the sun till they attained a constant weight. Then six different phytochemicals were extracted from each species following the protocol of Harborne (1992). This study was carried out at the Pharmacy laboratory of the University of Port Harcourt, Choba in Rivers State, Nigeria.

i. Detection of Alkaloids: To detect for alkaloids, extracts were dissolved individually in dilute Hydrochloric acid and filtered. Three tests were carried out namely:

(i.) Mayer's test in which the filtrates were treated with Mayer's reagent (i.e. Potassium Mercuric Iodide). The formation of a cream coloured precipitate indicated the presence of alkaloids.

(ii.) Dragendroff's test involved treating the filtrates with Dragendroff's reagent (i.e. solution of Potassium Bismuth Iodide). The formation of red precipitate indicates the presence of alkaloids.

c) Hager's test involved treating the with Hager's reagent (saturated picric acid solution). The presence of alkaloids is confirmed by the formation of yellow coloured precipitate.

ii. Detection of Saponins: To detect for saponins, two tests were carried out namely:

a) Froth test involved diluting the extracts with $20 \mathrm{ml}$ distilled water and shaken in a graduated cylinder for 15 minutes. The formation of $1 \mathrm{~cm}$ layer of foam indicates the presence of saponins.

b) Foam test involved shaking 0.5 gm of extract with $2 \mathrm{ml}$ of water to produce foam. If the foam produced persists for ten minutes it indicated the presence of saponins.

iii. Detection of Phytosterols: To detect for phytosterols, two tests were carried out namely:

a) Salkowski's test which involved treating the leaf extracts with chloroform and filtered. The filtrates were then treated with few drops of conc. Sulphuric acid, and shaken and allowed to stand. The appearance of golden yellow colour indicated the presence of triterpenes a type phytosterols.

b) Libermann-Burchard's test involved treating the extracts with chloroform and filtered. The filtrates were treated with a few drops of acetic anhydride, boiled and cooled. Then conc. sulphuric acid was added. The formation of brown ring at the junction indicated the presence of phytosterols.

$i v$. Detection of Phenols and Tannins: To detect for phenols and tannins, Ferric Chloride Test was carried out on extracts treated with 3-4 drops of Ferric Chloride solution. Formation of bluish black colour indicates the presence of phenols. For tannins, about $0.5 \mathrm{~g}$ of plant extract was stirred with $10 \mathrm{ml}$ of distilled water and filtered. $5 \%$ ferric chloride reagent was added to the filtrate. A blue-black, green or blue green 
precipitate is taken as evidence for the presence of tannins.

v. Detection of Flavonoids: To detect for flavonoids, Shinoda reduction test was carried out. A few pieces of magnesium metal were added to $5 \mathrm{ml}$ of each plant extract. The solution was obtained using conc. hydrochloric acid to dissolve the extract. The formation of orange, red crimson or magenta colouration was taken as evidence of preliminary presence of flavonoids.

Molecular characterization: The young leaves of the five Jatropha species were taken to the Regional Centre for Biotechnology and Bioresources, University of Port Harcourt, for the genomic DNA (gDNA) extraction. The extraction of DNA from the Jatropha species was carried out using the ZYMO Quick-DNA $^{\text {TM }}$ Plant/Seed Miniprep Kit (Zymo Research Group, California, USA). The gDNA quantity and concentration were measured using the Nanodrop 2000c spectrophotometer (Thermo fisher Scientific Inc. Wilmington, Delaware, USA). The DNA purity was measured as a ratio of absorbance at 280 nanometer $(\mathrm{nm})$ to that of 260 nanometer. The quality of the gDNA was further quantified using the Agarose gel electrophoresis performed according to the modified method of Saghai-Maroof et al. (1984). The gDNA samples were shipped to the International Institute of Tropical Agriculture (IITA) Bioscience Center, Ibadan, Nigeria for amplification and sequencing. The Ribulose-1, 5-biphosphate carboxylase $(r b c L)$ primers was used; the $r b c L-F$ as forward primers and $r b c L-\mathrm{R}$ as reverse primers, $r b c L$ F (5'-CCACAAACAGAGACTAAAGC -3') and rbcL-R (5'- GTAAAATCAAGTCCACCGCG -3') were used to amplify the fragments of nuclear ribosomal DNA (rDNA). The amplicons were sequenced using the ABI3500 capillary electrophoresis sequencer. The DNA sequence file was saved in the Bioedit file with extension .abl. The sequence was analyzed using the Molecular Evolutionary Genetics Analysis (MEGA) version 7.0.26 software, and aligned using the Basic Local Alignment Search Tool for nucleotide (BLASTN) 2.8.0 version of the National Center for Biotechnology
Information (NCBI) database which is global database containing information on different sequences. The alignment confirmed the identities of the plants.

Phylogenetic analysis: The data collected from the morphological and phytochemical studies were arranged in a binary format in which 1 was used to indicate that the character was present and 0 was used to indicate that the character was absent using the Microsoft excel software. The data was further subjected to cluster analysis using the neighborjoining function of the multivariate feature of the Paleontological Statistical software (PAST) by Hammer et al. (2001). Also, the DNA sequences from the molecular study were subjected to phylogenetic analysis using the neighbor-joining tree function in MEGA.

\section{RESULTS AND DISCUSSION}

Morphological characterization: The morphological characteristics of the five Jatropha species used in this study are presented in Plate 1 and Table 2. From the results, it was observed that all the five species were distinctly different from each other based on the plant habit, stem structure, the leaf margin shape, leaf colour and texture. However, they shared some features which indicated their similarity and relationship. From the results, all the species were monoecious, succulent shrub or small tree in habit with ever-green or semideciduous foliage.

\begin{abstract}
Although all species had stems that were erect, cylindrical and stout that were unarmed with scars, and had green apexes and pale brown at the bases, however, J. podagrica had swollen at the base (gout) while J. gossypifolia had purplish-red apex. Also, they all had flowers that were rosaceous in shape, unisexual, regular pentamerous and polypeptalous with contorted aestivation. However, their flower colours were different from whitish-green, yellowishgreen, reddish, reddish-orange and dark red for $J$. tanjorensis. J. curcas, J. multifida, J. podagrica and $J$. gossypifolia respectively.
\end{abstract}

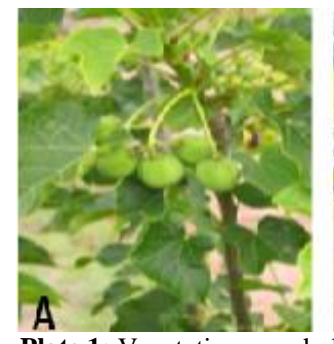

Plate 1: Vegetative morphology
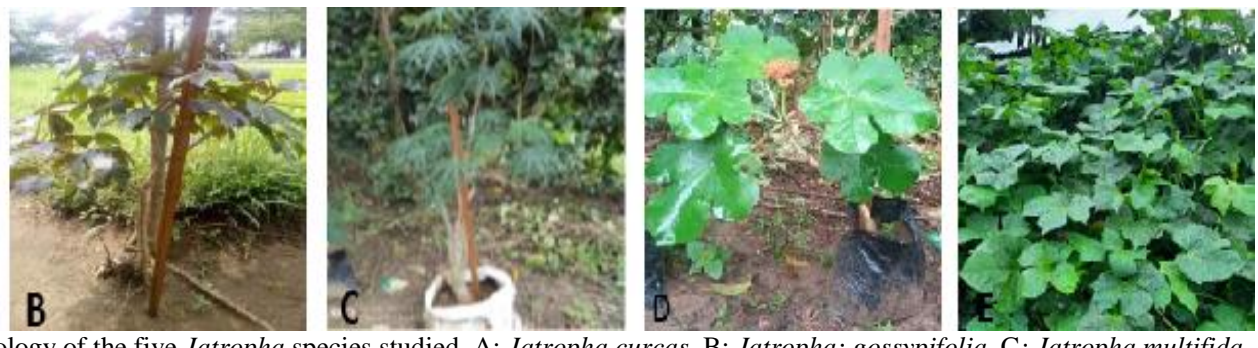

D: Jatropha podagrica, E: Jatropha tanjorensis 
Table 2: Summary of morphological characteristics of five Jatropha species

\begin{tabular}{|c|c|c|c|c|c|c|c|}
\hline $\mathbf{S} / \mathbf{N}$ & Character & Code & J.t & J.p & $J . m$ & $J . g$ & $J . c$ \\
\hline 1 & Plant habit (1=monoecious, 2_Not monoecious) & A1 & 1 & 1 & 1 & 1 & 1 \\
\hline 2 & Plant growth $(1=$ shrub $>5 \mathrm{~m}, 2=$ small tree $<5 \mathrm{~m})$ & A2 & 2 & 2 & 2 & 1 & 2 \\
\hline 3 & Foliage type ( $1=$ Evergreen, $2=$ not evergreen $)$ & A3 & 1 & 1 & 1 & 1 & 1 \\
\hline 4 & Root system ( $1=$ tap root, $2=$ fibrous root $)$ & A4 & 1 & 1 & 1 & 1 & 1 \\
\hline 5 & Stem type ( $1=$ erect and unarmed with scars, $2=$ not erect and armed) & A5 & 1 & 1 & 1 & 1 & 1 \\
\hline \multirow[t]{2}{*}{6} & Stem shape ( $1=$ cylindrical and stout, gout, with greenish apex and brown base, & & & & & & \\
\hline & $\begin{array}{l}2=\text { cylindrical and stout without gout with greenish apex and brown base, } 3=\text { cylindrical } \\
\text { and stout without gout with purplish apex and brown base }\end{array}$ & A6 & 2 & 1 & 2 & 3 & 2 \\
\hline 7 & Leaf type ( $1=$ foliage with green leaves, $2=$ foliage with purplish tinged leaves) & A7 & 1 & 1 & 1 & 2 & 1 \\
\hline 8 & Leaf oragnization $(1=$ simple, $2=$ nort simple $)$ & A8 & 1 & 1 & 1 & 1 & 1 \\
\hline 9 & Phyllotaxy (1=alternate, $2=$ opposite) & A9 & 1 & 1 & 1 & 1 & 1 \\
\hline 10 & Leaf shape ( $1=$ broadly ovate, $2=$ orbicularly ovate, & $\mathrm{A} 10$ & 1 & 2 & 1 & 1 & 1 \\
\hline 11 & Leaf lamina $(1=$ symmentrical, $2=$ assymmetrical $)$ & A11 & 1 & 1 & 1 & 1 & 1 \\
\hline 12 & Leaf base $1=$ shallowly cordate, $2=$ deeply cordate, $3=$ peltate & A12 & 2 & 3 & 2 & 1 & 2 \\
\hline 13 & $\begin{array}{l}\text { Type of leaf apex }(1=\text { acuminate tip, } 2=\text { altenate or tailed tip, } 3=\text { acute to acuminate tip, } \\
4=\text { acute or short acuminate tip }\end{array}$ & A13 & 1 & 1 & 2 & 3 & 4 \\
\hline 14 & Leaf texture ( $1=$ chartaceous, $2=$ cariaceous $)$ & A14 & 1 & 2 & 2 & 1 & 1 \\
\hline \multirow{2}{*}{$\begin{array}{l}15 \\
16\end{array}$} & Leaf surface ( $1=$ glabrous with whitish underside, $2=$ glabrous without whitish underside & A15 & 2 & 1 & 1 & 2 & 2 \\
\hline & $\begin{array}{l}\text { Forms of leaf margin }(1=\text { serrated or serrulate, } 2=\text { sinulate, } 3=\text { incised with projected } \\
\text { leaves, } 4=\text { entire and undulating) }\end{array}$ & A16 & 1 & 2 & 3 & 1 & 4 \\
\hline 17 & $\begin{array}{l}\text { Types of leaf lobes ( } 1=\text { palamtely lobed into } 3 \text { or } 5,2=\text { palmately lobed into } 3 \text { or } 7 \text {, } \\
\text { pinnatisect or palmately lobed into } 9-11)\end{array}$ & A17 & 1 & 1 & 3 & 1 & 2 \\
\hline 18 & $\begin{array}{l}\text { Shape of leaf lobe }(1=\text { more or less asymmetrical with acuminate tip, } 2=\text { narrow } \\
\text { oblanceolate with acuminate tip, } 3=\text { obovate to oblanceolate with acuminate tips, } 4=\text { ovate } \\
\text { with acute tips) }\end{array}$ & A18 & 1 & 1 & 2 & 3 & 4 \\
\hline 19 & $\begin{array}{l}\text { Type of Inflorescene ( } 1=\text { multiparous or polychaial cymose, } 2=\text { biparous or dichasial } \\
\text { cymose, } 3=\text { uniparous cymose) }\end{array}$ & A19 & 1 & 1 & 1 & 3 & 2 \\
\hline 20 & $\begin{array}{l}\text { Peduncle type ( } 1=\text { long and smooth, ending with a cyme and brancehed end, } 2=\text { long and } \\
\text { smooth, ending with a flowered leaf opposied cyme and branched, } 3=\text { long and smooth, } \\
\text { with a flat topped cluster or multiparous cyme and branched) }\end{array}$ & $\mathrm{A} 20$ & 3 & 3 & 3 & 2 & 1 \\
\hline 21 & $\begin{array}{l}\text { Flower description ( } 1=\text { rosaceous in shape, unisexual, regular pentamerous and } \\
\text { polypeptalous, yellowish-green in colour with a faint fragrance, } 2=\text { Rosaceous in shape, } \\
\text { unisexual, regular pentamerous and polypeptalous which is dark red in color and without } \\
\text { fragrance, } 3=\text { Rosaceous in shape, unisexual, regular pentamerous and polypeptalous } \\
\text { which is reddish in color and without fragrance, } 4=\text { Rosaceous in shape, unisexual, } \\
\text { regular pentamerous and polypeptalous which is reddish-orange in color and without } \\
\text { fragrance, } 5=\text { Rosaceous in shape, unisexual, regular pentamerous and polypeptalous } \\
\text { which is whitish-green in color and with a faint fragrance) }\end{array}$ & $\mathrm{A} 21$ & 5 & 4 & 3 & 2 & 1 \\
\hline 22 & $\begin{array}{l}\text { Bract type }(1=\text { persistent, } 2=\text { leafy and foliacerous, } 3=\text { Leafy and foliacerous with serrated } \\
\text { margins with angular tips }\end{array}$ & A22 & 1 & 1 & 1 & 3 & 2 \\
\hline 23 & Aestivation $(1=$ consorted, $2=$ not consorted & A23 & 1 & 1 & 1 & 1 & 1 \\
\hline 24 & $\begin{array}{l}\text { Form of sepal and corolla }(1=\text { petaloid and polypetalous and polyseppalous, } 2=\text { not } \\
\text { petaloid and polypetalous and polyseppalous })\end{array}$ & A24 & 1 & 1 & 1 & 1 & 1 \\
\hline 25 & $\begin{array}{l}\text { Sepal shape ( } 1=\text { ovate to obovate in shape and non-glandular margins, } 2=\text { lanceolate to } \\
\text { elliptical in shape with glandular margins, } 3=\text { broadly deltoid in shape })\end{array}$ & A25 & 1 & 1 & 1 & 2 & 3 \\
\hline 26 & Sepal texture ( $1=$ glabrous, $2=$ glabrous with pubscent surface with whitish hairs) & A26 & 1 & 1 & 1 & 1 & 2 \\
\hline 27 & Corolla shape ( $1=$ Elliptic , $2=$ Obovate a, $3=$ Oblanceolate to elliptical in shape) & A27 & 1 & 1 & 1 & 2 & 3 \\
\hline 28 & Corolla texture ( $1=$ glabrous, $2=$ Glabrous with pubescent surface with whitish hairs) & A28 & 1 & 1 & 1 & 1 & 2 \\
\hline 29 & Number of floral gland ( $1=5$ free glands, $2=$ no free 5 glands $)$ & A29 & 1 & 1 & 1 & 1 & 1 \\
\hline 30 & Male flower more than female flower ( $1=y e s, 2=$ no) & $\mathrm{A} 30$ & 1 & 1 & 1 & 1 & 1 \\
\hline 31 & $\begin{array}{l}\text { Position of ovary in the flower ( } 1=\text { superior or hypogynous, } 2=\text { not superior or } \\
\text { hypogynous) }\end{array}$ & A31 & 1 & 1 & 1 & 1 & 1 \\
\hline 32 & $\begin{array}{l}\text { Pistil type ( } 1=\text { Elliptic sycarpous, } 3 \text {-celled, triovulate, } 3 \text { spreading bifurcate style that is } \\
\text { fused at the base with } 2 \text {-lobed stigma per style, } 2=\text { Globose sycarpous, } 6 \text {-ripped and } 3 \text { - } \\
\text { celled, triovulate, } 3 \text { spreading style that is fused at the base with } 2 \text {-lobed stigma per style) }\end{array}$ & A32 & 2 & 2 & 1 & 2 & 1 \\
\hline 33 & Fruit type $(1=$ simple, $2=$ not simple $)$ & A33 & NA & 1 & 1 & 1 & 1 \\
\hline 34 & Fruit shape ( $1=$ globrose capsule and 3 -seeded, $2=$ ellipsoid capsule and 3 -seeded) & A34 & NA & 1 & 2 & 1 & 2 \\
\hline 35 & Fruit texture ( $1=$ glabrous, $2=$ pubescent with white hair) & A35 & NA & 1 & 0 & 1 & 0 \\
\hline 36 & Fruit dehiscence $(1=$ septicidal, $2=$ septifrugal $)$ & A36 & NA & 1 & 2 & 1 & 2 \\
\hline 37 & $\begin{array}{l}\text { Seed description ( } 1=\text { Ellipsoid with dark brown aril, } 2=\text { Ellipsoid with to triangular } \\
\text { convex with dark brown aril, } 3=\text { oval shape with dark brown aril })\end{array}$ & $\mathrm{A} 37$ & NA & 1 & 3 & 1 & 2 \\
\hline 38 & Number of seed per fruit $(1=3,2=$ more than 3$)$ & $\mathrm{A} 38$ & NA & 1 & 1 & 1 & 1 \\
\hline 39 & $\begin{array}{l}\text { Seed dispersal }(1=\text { Fruit dehisces and the seed are released by explosion, } 2=\text { Fruit dehisces } \\
\text { but seeds remain intact till fruit drops to the ground })\end{array}$ & A39 & NA & 1 & 2 & 1 & 2 \\
\hline
\end{tabular}

J. t: Jatropha tanjorensis, J. p: Jatropha podagrica, J. m: Jatropha multifida, J. g: Jatropha gossypifolia, J. c: Jatropha curcas NA: not available 
Phytochemical characterization: The results of the phytochemical studies are presented in Table 3. From the results it was observed that all the six phytochemicals namely alkaloids, tannins, flavonoids, saponins, phytosteroids, and phenols were present in the leaves of the five Jatropha species but at different levels of concentrations. For alkaloids, Jatropha multifida had more alkaloids that the other four
Jatropha species. For tannins, Jatropha curcas and Jatropha gossypifolia had more tannins that the other three Jatropha species. For flavonoids, Jatropha curcas had more flavonoids than others, however, it was not found in Jatropha multifida. The leaf of Jatropha podagrica had more saponins than the other Jatropha species. Phytosteroids and phenols were present in all the Jatropha species.

Table 3: Phytochemicals present in the leaves of five Jatropha species studied

\begin{tabular}{|c|c|c|c|c|c|c|c|}
\hline Jatropha species & $\begin{array}{l}\text { Plant } \\
\text { part }\end{array}$ & Alkaloids & Tannins & Flavonoids & Saponins & Phytosteroids & Phenols \\
\hline Jatropha podagrica & Leaf & ++ & ++ & ++ & +++ & ++ & + \\
\hline Jatropha tanjorensis & Leaf & ++ & ++ & + & ++ & + & + \\
\hline Jatropha curcas & Leaf & ++ & +++ & +++ & ++ & + & ++ \\
\hline Jatropha multifida & Leaf & +++ & ++ & - & ++ & ++ & + \\
\hline Jatropha gossypifolia & Leaf & ++ & +++ & ++ & ++ & ++ & ++ \\
\hline
\end{tabular}

Cluster analysis based on morphological and phytochemical attributes: The result of the cluster analysis of the relationship of the five Jatropha species based on the morphological and phytochemical characteristics are presented in Figure 1 and Table 4. From the result, it was observed that the five common Jatropha species were divided into two main clusters. The first cluster included four Jatropha species namely J. curcas, J. multifida, J. tanjorensis, J. podagrica while J. gossypifolia belonged to the second cluster. The species $J$. gossypifolia had a distance indices of 6.226, 6.164, 6.928 and 6.708 from J. tanjorensis, J. podagrica, J. multifida and $J$. curcas respectively. The first cluster was further sub-divided into two subgroups in which $J$. curcas was in the first subgroup while $J$. multifida, $J$. tanjorensis, and J. podagrica clustered in the second subgroup. The second sub-group was further divided into two subgroups in which $J$. multifida, and $J$. tanjorensis, clustered together into a group. The highest distance index was7.280 which was between $J$. curcas and J. podagrica, thus indicating that they were highly dissimilar, which $J$. multifida, and $J$. tanjorensis had the lowest distance index of 5.050 indicating that they were may be more closely related than the other species.

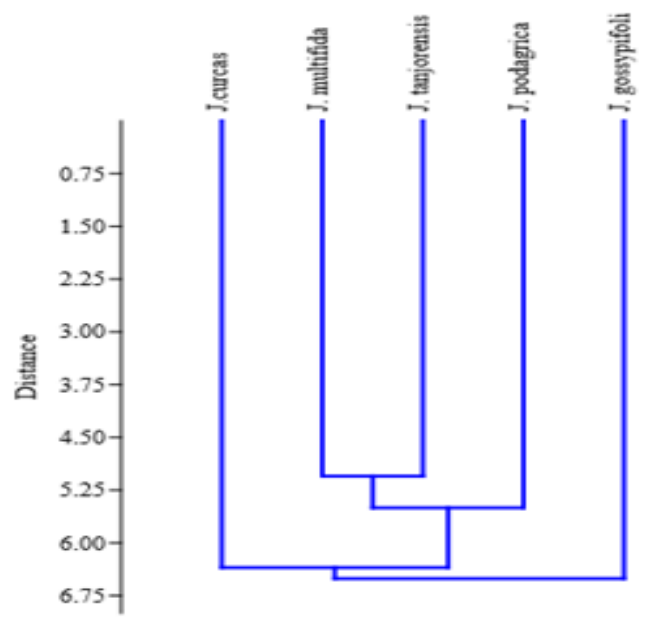

Fig 1: Cluster (classical) analysis indicating the relationship among five common Jatropha species based on the morphological and phytochemical characters.

Table 4: The similarity and distance indices of the five Jatropha species

\begin{tabular}{llllll}
\hline & J. tanjorensis & J.podagrica & J. multifida & J. gossypifolia & J.curcas \\
\hline J. tanjorensis & 0 & & & & \\
J. podagrica & 5.344 & 0 & & & \\
J. multifida & 5.050 & 5.657 & 0 & & \\
J. gossypifolia & 6.226 & 6.164 & 6.928 & 0 & 0 \\
J.curcas & 5.532 & 7.280 & 6.245 & 6.708 & \\
\hline
\end{tabular}

Molecular Analysis: The result of the phylogenetic analysis of the DNA sequences of the five Jatropha species is presented in the dendrogram in Figure 2. From the dendrogram, it was observed that the five Jatropha species were separated into two clusters: Cluster 1 was made up of four Jatropha species namely $J$. multifida, J. podagrica, J. tanjorensis, and
J. curcas, while Cluster 2 had only J. gossyipflia. This indicated that the Jatropha species in cluster 1 are more closely related than J. gossyipflia in cluster 2 . Also, cluster 1was further divided into two subclusters A and B. J. multifida, J. podagrica, J. tanjorensis were grouped into sub-cluster A while $J$. curcas was grouped into sub-cluster B. This indicates 
that although the four Jatropha species namely $J$. multifida, J. podagrica, and J. tanjorensis are more closely related. However, sub-Cluster A was further sub-divided into two groups, with $J$. multifida and $J$. podagrica clustering together and $J$. tanjorensis grouped into a separate group. This finding indicates that among the five Jatropha species, J. multifida and $J$. podagrica are more closely related.

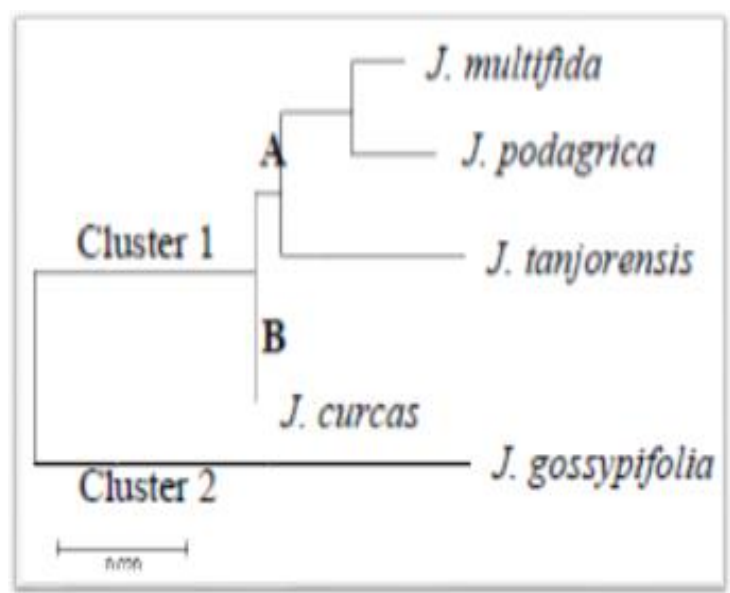

Fig 2: A dendrogram illustrating the phylogenetic relationships of the five Jatropha species based on Ribulose-1, 5-biphosphate carboxylase (rbcl) molecular marker.

The genetic diversity of the highly distinctly different Jatropha species is critical to establish strategies for conservation and genetic breeding for the improvement of these income security plants. Therefore, the genetic relationship among the different Jatropha species needs to be cataloged. The present study was aimed to investigate the morphological, phytochemical and molecular phylogenetic affinity among the five Jatropha species. These three taxonomic lines of evidence are important and had been used in the elucidation of Jatropha species in Egypt (El-Mewafy et al., 2016). From the gross morphology, it was observed that all the five species were distinctly different from each other based on their vegetative and reproductive features. However, they shared some features which indicated their similarity and relationship. For instance, all species had stems that were erect, cylindrical and stout that were unarmed with scars, and were pale brown coloration at the stem bases, however, J. podagrica had swollen base (gout) while J. gossypifolia had purplish-red apex. Also, all species had different flower colours from whitish-green, yellowish-green, reddish, reddish-orange and dark red for J. tanjorensis. $J$. curcas, J. multifida, J. podagrica and J. gossypifolia respectively. However their flowers were rosaceous in shape, unisexual, regular pentamerous and polypeptalous with contorted aestivation. These characteristics have been reported as important traits for the elucidation of Jatropha species (Ratha and Paramathma, 2009, Nwokocha et al., 2012). Phytochemical analyses for medicinal properties have shown that numerous compounds in plant traditionally used for medicinal purpose have chemical properties that are effective in treating illness. Phytochemicals are chemical compound formed during the plant normal metabolic process and are often referred to as secondary metabolite of which there are several classes including alkaloids, flavonoids, saponins, coumarins, steroids, glycosides, gum, phenol, tannins, terpenes and terpenoids (Harborne, 1973: Okwu, 2004). The presence of secondary metabolites in the different Jatropha species at different levels of concentrations are taxonomically useful; and indicates that Jatropha species are potential sources of these important phytochemicals (Nwokocha et al., 2011). In this study, six phytochemicals namely alkaloids, flavonoids, tannins, saponins, phytosteroids and phenols were present but at different levels of concentrations in the leaves of the five Jatropha species studied. The presence of these phytochemicals confirmed the relatedness of these five Jatropha species. However, the variability in the concentrations of these phytochemicals confers individuality on the species. Also, from this study, Jatropha curcas and Jatropha gossypifolia were observed to have more tannins that the other three Jatropha species. While Jatropha curcas had more flavonoids than the rest. Also, from this study, it was observed Jatropha tanjorensis had a very high concentration of alkaloid. Alkaloids are very important component that explains why this plant is being used for the treatment of illnesses such as malaria since most alkaloidal plants have high antimalarial activity (Viswanathan et al., 2012). These secondary metabolites identified in these Jatropha species have been reported in several other plants used for curative activity against various pathogens, used traditionally as analgesic and soothing herbs (El-Mewafy et al., 2016). The use of molecular marker technique has been employed to authenticate the identification and relationship of organisms (Gontia-Mishra et al., 2013; Bechem and Afanga, 2017). The use of molecular marker has been employed in the taxonomic elucidation of Jatropha species (Tanya et al., 2011, El-Mewafy et al., 2016). In the study, this technique showed the relatedness of five distinctly different Jatropha species, by comparing their DNA sequence. The phylogenetic analysis resulted in a dendrogram that revealed the affinity and diversity of the five Jatropha species studied. This is reported for the first time in Niger Delta and further builds on the works reported by Nwokocha et al., (2011; 2012). From the two cluster analysis conducted in this study, it was observed that the five Jatropha species were segregated into two 
major clusters. El-Mewafy et al. (2016) had made similar observation among the commonly occurring Jatropha species in Egypt. Among the five Jatropha species, J. gossypifolia was the only species that clustered separately. This may be as a result of its unique and distinctive purplish colour of its leaves, stem and flower. Also, from the first groups of the two clusters, it was observed that J. tanjorensis, $J$. multifida, and $J$. podagrica clustered in the same subgroup, while J. curcas segregated into another group. Despite the dissimilarity of J. curcas and $J$. gossypifolia, a natural interspecific hybrid between had been found and classified as $J$. tanjorensis (Prabakaran and Sujatha 1999). Yet in this study, $J$. tanjorensis did not segregate and cluster with J. curcas or J. gossypifolia. Therefore, further investigation is needed to establish the phylogeny of J. tanjorensis. Moreover, the segregation of $J$. tanjorensis with $J$. multifida, and $J$. podagrica into one group may indicate that this species is more closely related to $J$. multifida, and J. podagrica than J. curcas and $J$. gossypifolia. Hybridization among these three species will contribute to the improvement program of Jatropha species.

Conclusion: The comparison of five common but distinctly different Jatropha species found in some parts of Niger Delta was done using morphological, phytochemical and molecular marker methods to establish their affinity. From the cluster analysis, it was observed that the five Jatropha species, are divided into two major groups. The species, $J$. gossypifolia was the only species that clustered separately from the other Jatropha species. The species, J. tanjorensis, J. multifida, and J. podagrica, clustered together indicating that they are more closely related.

\section{REFERENCES}

Argolo-marques, D; Sigueira, WJ; Colombo, CA and Ferrari, RA (2013). Breeding and Biotechnology of Jatropha curcas. In: Jatropha, Challenge for a new energy crop: V.2: Genetic improvement and Biotechnology: $1^{\text {st }}$ edn (Bahadur, B., Sujaha, M. Carels, N., eds). Springer Science business mediar, New York Pp. 7-23.

Banerji, R; Chowdbury, AR; Misra, G; Sudarsanam, G; Verma, SC and Srivastava, GS (1985) Jatropha curcas seed oil for energy. Biomass, (8): 277-282.

Basha, SD and Sugatha, M (2007). Inter and intrapopulation variability of Jatropha curcas (L). Characterized by RAPD and ISSR markers and development of population specific SCAR markers, Euphytica, (156): 375-386.

Bechem, ET and Afanga, YA (2017). Morphological and molecular identification of fungi associated with corm rot and blight symptoms on plantain (Musa paradisiaca) in macro-propagators. Inter.Bio. Chem. Sci. 11(6): 2793-2808.

El-Mewafy, A; El Mewafy EG; Omneya, FAE and Ehab MBM. (2016). Morphological, Phytochemical and Molecular Characterization on Some Jatropha Species Cultivated In Egypt. International Journal of Pharma Sciences and Scientific Res. 3:1, 1-13.

Gill, LS (1988). Taxonomy of Flowering Plants. Africana-Fep Publishers limited. Pp 69-107.

Gontia-Mishra, I; Deshmukh, D; Tripathi, N; BardiyaBhurat, K; Tantwai, K and Tiwari, S (2013). Isolation, Morphological and Molecular Characterization of Phytate-Hydrolysing Fungi by $18 \mathrm{~S}$ rDNA Sequence Analysis. Brazilian $J$. Microbio. 44:1.

Hammer, Ø; Harper, DAT and Ryan, PD (2001). PAST: Paleontological Statistics Software Package for Education and Data Analysis. Palaeontologia Electronica, 4(1): 9.

Harborne JB (1992). Phytochemical Methods. A Guide to Modern Technique of Plant Analysis Chapman and Hill, London; pp: 279-282.

Heller, J (1996). Physic Nut (Jatropha curcas L.): Promoting the conservation and use of underutilized and neglected crops. Rome: institute of plant genetics and crop plant research.

Hutchinson, J and Dalziel, JM (1954). Flora of West Tropical Africa. Revised by Keay, R.W.J. Vol. 1 part 1. Crown Agent for Oversea Government and Administration. London. Pp 396-397.

Li, Y; Kui-Hua, L and Ling-Hui, W (2009). Jatropha curcas resources distribution and applied research. Gungxi Agricultural Science, (40): 311 314.

Nwokocha BA (2010). Comparative studies of four species of Jatropha L. (Euphorbiaceae) in Delta and Rivers States of Niger Delta. MSc thesis. Department of Plant Science and Biotechnology, University of Port Harcourt, Rivers State, Nigeria. 
Nwokocha, BA; Agbagwa, IO and Okoli, BE (2011). Comparative phytochemical screening of Jatropha L. species in the Niger Delta. Research Journal of Phytochemistry, 7 (5): 163-175.

Nwokocha, BA; Agbagwa, IO and Okoli, BE (2012). Vegetative and Floral Morphology of Jatropha species in the Niger Delta. J. Plant Sci. 7 (5): 163 175.

Okwu, DE (2004). Phytochemicals and vitamin content of indigenous spices of South Eastern Nigeria. J. Sustain. Agric. Environ. 6(4): 30-34.

Ratha, PK and Paramathma, M (2009). Potentials and Jatropha species wealth of India. Current Sci. 97:1000-1004.

Sudheer, PDVN; Pandya, N; Reddy, MP and Radhakrishran, T (2008). Comparative study of interspecific genetic divergence and phulogenic analysis of genus Jatropha by RAPD and AFLP. Molecular Biological Repository, 9261
Tanya, T; Tacprayoon, P; Hadkam, Y, and Srinives, P, (2011). Genetic diversity among Jatropha and Jatropha-Related species based on ISSR markers. Plant Molecular Biology Repository, 29(1): 252264.

Tekade, Y (1982). Development study on Jatropha curcas (sabu dom) oil as a substitute for diesel engine oil in Thailand. J. Agric. Assoc. China, 120:181-188.

Viswanathan MB; Ananthi JDJ and Kumar PS (2012). Antimicrobial activity and bioactive compounds and leaf extract in $J$. tanjorensis. Fitoterapia, $83: 1153-1159$.

Wenjum, O; Wang, W and Li, K (2008). Discuss the status and development strategies of energy plants Jatropha curcas L. Chinese Agric. Bull. 24: 496499. 